\title{
RESOURCE POTENTIAL APPRAISAL / ASSESSMENT AND TO DELINEATE GROUNDWATER POTENTIAL ZONES IN PARTS OF ANAIMALAI, POLLACHI AND UDUMALPETBLOCK USING REMOTE SENSING AND GIS
}

\author{
M.Pandian ${ }^{1}$, M.Julie ${ }^{2}$, Y. Allwyn Fernandes ${ }^{3}$, SK Mahammad Sartaj Basha ${ }^{4}$ \\ ${ }^{1}$ M.Tech, Student, ${ }^{4}$ Res.Associate, Centre for Remote Sensing, Bharathidasan University, Khajamalai Campus, Trichy-23 \\ ${ }^{2} M E$, Student, Institute of Remote Sensing, College of Engineering, Anna University, Guindy, Chennai-25 \\ ${ }^{3}$ M.Tech, Student, Remote Sensing, Dept. of Civil Engg, PSNA College of Engg, \& Tech, Dindigul -22
}

mahapandian@hotmail.com

\begin{abstract}
Remote sensing has its application in various fields like geology and mineral exploration, geomorphology and modern geomorphic process modeling, nature mitigation studies, hazard zone mapping, eco system study in hills, plains, riverine, coastal, marine and volcanic landforms, forest and biomass inventory, fishery. Remote sensing plays a vital in various fields. This technique along with the GIS has been to study the geomorphological, hydro geological, land use/land cover, lithological, structural aspects/ features in the parts of Anaimalai, Pollachi and Udumalpet block of TamilNadu. Integrated approach using geographic information system provides cost effective support in resources inventory including land use mapping, comprehensive data base for resources, analytical tools for decision making and impact analysis for plan evaluation. GIS accept large volumes of spatial data derived from a variety of sources and effectively store, retrieve, manipulate, analyze and display all forms of geographically referenced information. Maps and statistical data can be obtained from the spatial integration and analysis of an area using GIS software. In order to assess the natural resource availability and its potentiality in parts of Anaimalai, Pollachi and Udumalpet block, Tamil Nadu, an integrated remote sensing and GIS based study has been conducted by adopting the standard procedures. The groundwater potential zone of any area is depends on geological formations; geomorphologic unit's recharges characters, topography, and thickness of weathered and fractured zones. In the present study, area was taken to locate groundwater potential zones by integrated different thematic maps, remote sensing and geographic information system techniques. To find out the ground water potential zones, different thematic maps have been prepared and integrated each of them. They are mainly geology, geomorphology, land use / land cover, lineament etc. Groundwater potential zones have been prepared with help of integrating different thematic maps. This study area is finally to get the groundwater potential zones we have to classified few area such as high, moderate and low potential zones.
\end{abstract}

Index Terms: Remote sensing, GIS, lithology, Geomorphology, Hydrology, landforms etc.

\section{INTRODUCTION}

Remote sensing techniques are efficient, accurate and cost effective. Remote sensing data along with ground truth information and other collateral data have been extensively used to survey various natural resources. Remote sensing techniques along with GIS technology also processes the unique capabilities to model, animate and retrieves various spatial and non-spatial information's including the modern dynamic processes. To achieve the utilizes of remote sensing and GIS techniques on up graduation of terrain information. The enormous infrastructure of what are collectively known as utilizes, i.e., water, gas, telephone lines, sewage system all need to be recorded and manipulated in map form. GIS can play a vital role in managing these utilizes.

\section{AIM AND OBJECTIVES}

The main aim and objective of the present investigations are, to prepare the thematic maps such as, geology, Landuse and Landcover, geomorphology, lineament, drainage and soil of the study area. To demarcate the suitable zones for drilling bore wells and dug wells. To prove the usage of the remote sensing and geographic information system techniques to delineate the potential zones of groundwater 


\section{STUDY AREA}

The area chosen for the present study lie between the latitude 100 20" 00 ' and 100 40' 00 ' $\mathrm{N}$ and longitude 760 50" 00' and 77010 " 00 ' $\mathrm{E}$ in the survey of India Toposheet no $58 \mathrm{~B} / 14$, $58 \mathrm{~B} / 15,58 \mathrm{~F} / 2$, and $58 \mathrm{~F} / 3$ and the total study area is 813.86 Sq.km. In general study area is a plain terrain with slight undulation and with structuralhill. The ground surfaces on the Southern side of Aliyar River generally slope towards North East and ground surface on the Northern side of Noyyal River.

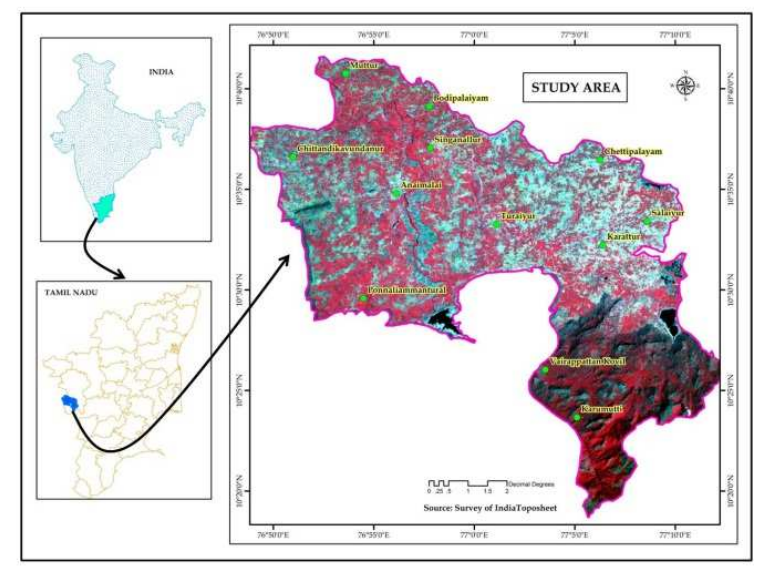

Figure.1 Location of the Study area

\section{MATERIALS AND METHODOLOGY}

In the present study geocoded the IRS - P6 LISS III satellite imagery data in the scale on 1:50,000. Both satellite data and topographic sheet were used for the generation of various thematic maps. The following maps (base map, drainage) were prepared by making use of survey of India Toposheet. The methodology includes the generation of thematic layers on lithology, structure (lineament, trend line), geomorphology (landforms), Landuse/Landcover, hydrology (water bodies, streams, etc.,) based on their image characteristics (interpretation key and elements like tone, texture, pattern shape, size, and drainage characteristics). A lineament map was generated using the satellite data. This can be used to see the possible relationship between lineament distribution and their control on the ground water. Geographic information system (Arc GIS software 9.3.1 and surfer 10) was used for the mapping of individual layers and final integration of map. Based on the character, the features in different thematiclayers were assigned with different weightages values according to the potential for groundwater.After the layerswere integrated using GIS and then the area can be classified as high, moderate and low groundwater potentialzones.

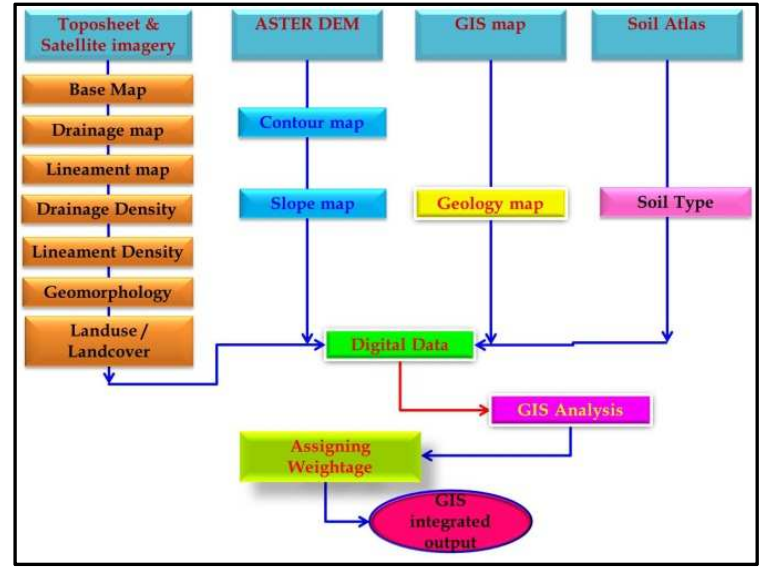

Figure.2 Flowchart showing methodology

\section{DRAINAGE AND DRAINAGE DENSITY}

Drainage map has been prepared in the scale of 1:50,000 from the topographic sheet no $58 \mathrm{~B} / 14,58 \mathrm{~B} / 15,58 \mathrm{~F} / 2$, and $58 \mathrm{~F} / 3$. And from this map it is inferred that a major river Aliyar river is flowing from west to east of the study area. Except these other small drainages are flowing in the study area from south west to north east to the south of Aliyar River. The drainage density map is total length of the drainage in a grid of unit area. Drainage map is prepared.

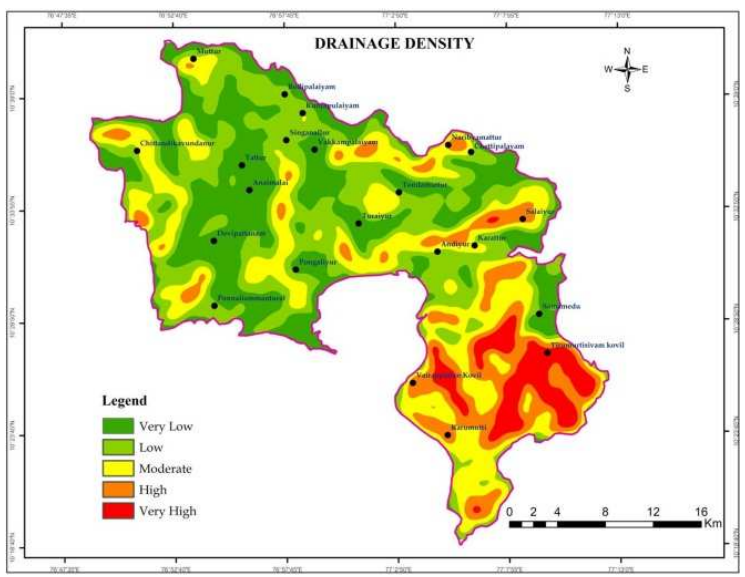

Figure.3 drainage density map

\section{LINEAMENT AND LINEAMENT DENSITY}

Lineaments is defined as map able simple or composite feature of a surface, whose parts are aligned in a straight or slightly curving relationship and which differs distinctly from the patterns of adjacent features an presently reflect a subsurface phenomenon. The surface feature making up a lineament may be geomorphic or tonal. The intersection, frequency of lineaments and their densities can also be plotted and density contour drawn. 


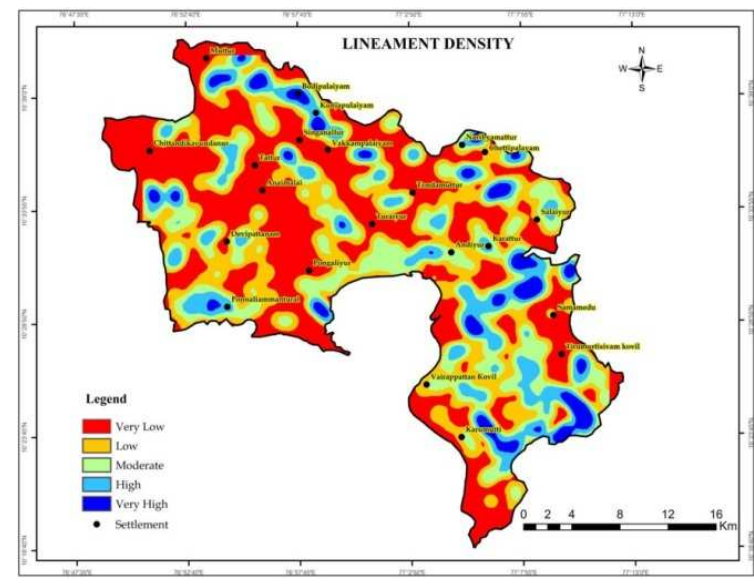

Figure.4 lineament density map

\section{SOIL MAP}

For the preparation of the soil map, the soil atlas of the Coimbatore and Tiruppur districts is used as the primary sources. At first the soil map unknown scale is traced out with some control points. After that this unknown scale map is brought to require scale $1 ; 50,000$ using pantograph. This is then traced to a tracing film to prepare thematic map of soil.

Table.1 Assigned weight age for soil map

\begin{tabular}{|l|l|l|l|}
\hline Features & $\begin{array}{l}\text { Area in } \\
\text { (Sq.km) }\end{array}$ & Weight ages & Rank \\
\hline $\begin{array}{l}\text { sandy Loam, } \\
\text { Sandy Clay } \\
\text { Loam, } \\
\text { Gravelly } \\
\text { Sandy Clay }\end{array}$ & 466.975 & 1 & High \\
\hline $\begin{array}{l}\text { Sandy Clay } \\
\text { Loam, Clay } \\
\text { Gravelly Cankar } \\
\text { Loam, Kan } \\
\text { Bed }\end{array}$ & 88.059 & 2 & Medium \\
\hline $\begin{array}{l}\text { sandy clay } \\
\text { loam }\end{array}$ & 33.762 & 2 & \\
\hline clay loam & 14.722 & 3 & Low \\
\hline Clay & 165.983 & 3 & \\
\hline
\end{tabular}

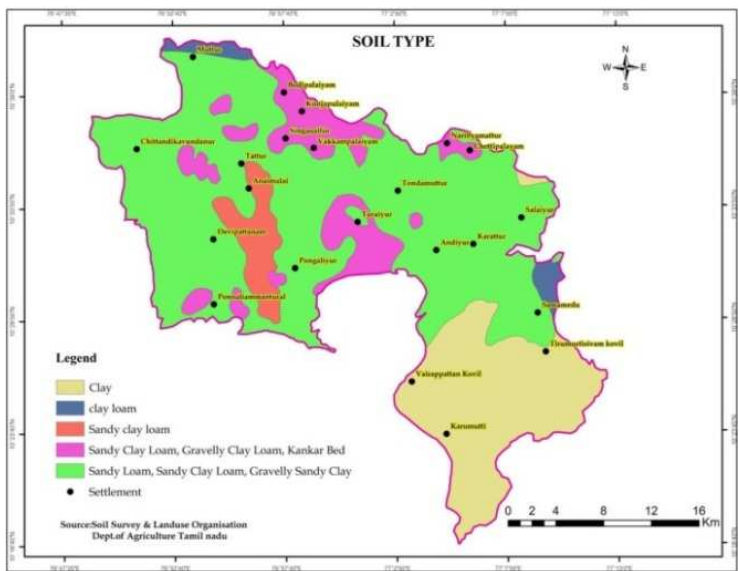

Figure.5 soil map

\section{GEOMORPHOLOGY}

The central and eastern part of the study area includes the pollachi, anaimalai and udumalpet. The pediment in the area can be further subdivided as buried pediment deep, buried pediment medium and buriedpediment shallow. This is grouped on the basis of the photo key and their and association.

\subsection{Inselbergs}

Inselbergs are isolated hillocks which are remnants of weathering and denudation. Inselbergs are mostly barren rocky. From the ground water point of view these units are treated neither contain nor transmit water. These units mostly act as runoff zones. It is identified in the imagery by its isolated nature, darker tone without vegetation.

\subsection{Landforms of Fluvial Origin}

The landforms of fluvial origin are identified along the river courses of the study area. It is represented by alluvium consisting of sand and silt. It's formed mainly due to the fluvial actively of the major rivers in the study area. Major part of the area is covered by fluvial features. Major rivers flowing in this area is Aliyar River

\subsection{Flood Plain}

In mature stage normally rivers floods on either banks and deposits unconsolidated sediments which is called as flood plain. This flood plain, Will have loose sediments, hence retain good moisture, hence patronize more vegetal cover and agriculture, hence easily discernible in black and white photographs in black color and color coded photographs reddish color.

Sometimes these rivers will develop flood plain on one side which suggests that the rivers are migrating towards the direction of on flood plain; such areas must be avoided for dam construction and culvert construction. 


\subsection{Pediment}

These are gently sloping bed rock surface terminating against the mountain front, usually by a sharp in slope. Pediments are identified as gently undulating rock floored surface without weathered mantle, but often partly mantled with thin veneer of soil obtained from the upland masses bordering the hills. These are for by combination of processes, such as back weathering, sheet wash and lateral erosion. These zones are generally low permeable with poor infiltration and are considered to be the runoff zones. In the satellite IRS $1 \mathrm{C}$ imagery pediment is identified by their gray to yellow tone, medium texture, highly irregular pattern and close association with the foot hills indicates the pediments where the slope is low to moderate, gently the left out rocky materials preen over here.

Table.2 assigned weightage for Geomorphology map

\begin{tabular}{|c|c|c|c|}
\hline Features & $\begin{array}{l}\text { Area in } \\
(\mathrm{Sq} . \mathrm{km})\end{array}$ & Weightages & Rank \\
\hline Flood plain & 119.857 & 1 & \multirow{3}{*}{ High } \\
\hline $\begin{array}{l}\text { Buried } \\
\text { pediment }\end{array}$ & 466.866 & 1 & \\
\hline water body & 2.730 & 1 & \\
\hline $\begin{array}{l}\text { Shallow } \\
\text { pediment }\end{array}$ & 10.899 & 2 & Medium \\
\hline Inselberg & 4.180 & 3 & \multirow{4}{*}{ Low } \\
\hline Valley fill & 11.924 & 3 & \\
\hline Ridges & 7.9030 & 3 & \\
\hline $\begin{array}{l}\text { Structural } \\
\text { hill }\end{array}$ & 146.052 & 3 & \\
\hline
\end{tabular}

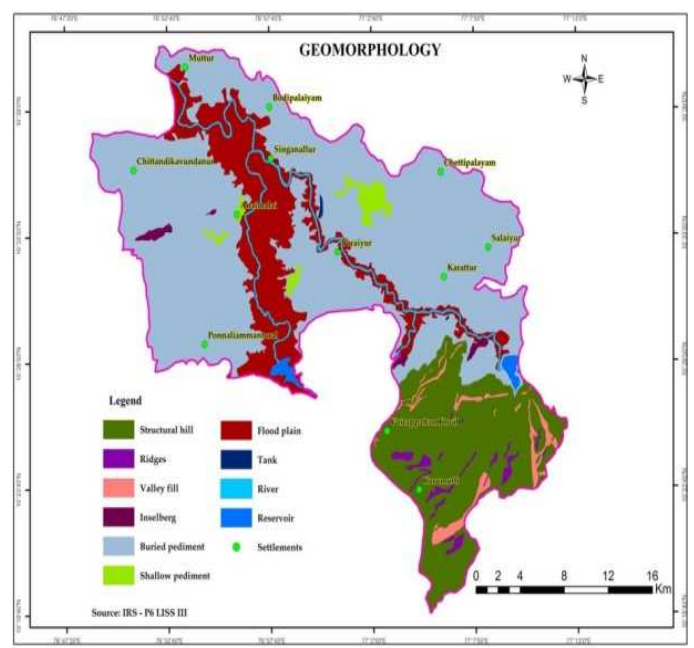

Figure.6 geomorphology map

\section{LAND USE AND LAND COVER}

Information on the rate of changes in land resources is essential for proper planning, management and regulating the use of such resources. Under a given climate condition the growth and yield of the crop is determinate by available nutrients and water supplies, which are taken up from the soil and hence it should be carefully managed. Good cultivable soils are not only limited but also unevenly distributed. Often the improper land use is causing various forms of environmental degradations for sustainable utilization of the land ecosystem, it essential to know the nature, characteristics, extent, and location of soil resources, its quality, productivity, sustainability and limitations for various land uses. The IMSD guide lines NRSA have been followed and prepared the land use / land cover classifications. Land use refers to mean's activities and various use which are carried up land. Landcover refer to natural vegetation, water bodies' rock / soil, artificial cover and other resulting due to land transformations. The study classified into several of Land use / Landcover classes by visual interpretation. Classes such as built up land, crop land, fallow land, barren rocky, landwith scrup, plantation, wet logged area and water bodies

Table.3 assigned weightage for Landuse / Landcover map

\begin{tabular}{|c|c|c|c|}
\hline Features & $\begin{array}{l}\text { Area in } \\
\text { (sq.km) }\end{array}$ & Weightages & Rank \\
\hline Crop land & 339.55 & 1 & \multirow{5}{*}{ High } \\
\hline Waterbodies & 5.98 & 1 & \\
\hline Plantation & 117.347 & 1 & \\
\hline Wet logged & 5.115 & 1 & \\
\hline Landwith scrub & 0.060 & 1 & \\
\hline Builtup land & 0.909 & 2 & Medium \\
\hline Barren Rocky & 63.379 & 3 & \multirow[b]{2}{*}{ Low } \\
\hline Fallow land & 237.150 & 3 & \\
\hline
\end{tabular}

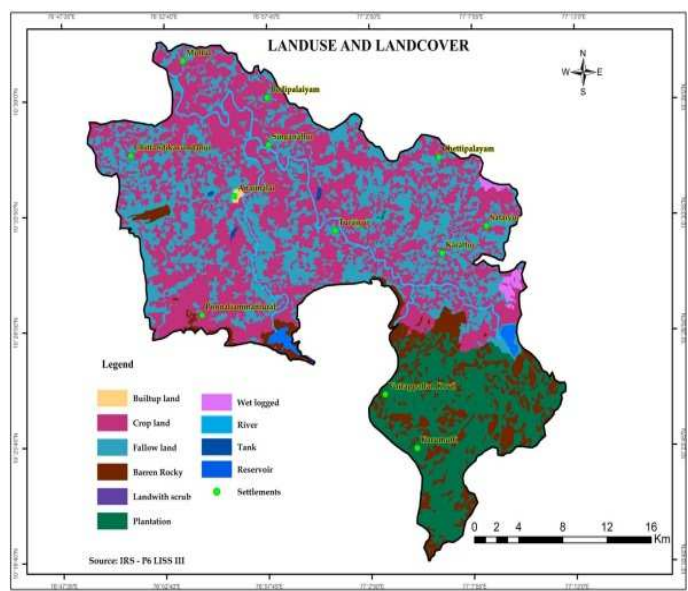

Figures.7 land use / land cover map 


\section{GEOLOGY}

Geologically the study area is predominantly comprised of the peninsular gneiss of Archean age and intrusive body of quartzite's veins. There are three major types are observed in the study area, such as granite gneiss, hornblende Biotite gneiss and a linear pockets of quartzite intrusions.

The geology of the investigated area has been delineated in the satellite imageries. Visual interpretation techniques carried out based on the photo recognition elements like tone, texture, and color, bordered information of the object, drainage pattern, and differential erosional characteristics and associated of the structural features of the exposed litho-stratigraphic units. The lithological map of the area prepared, and supported by collateral data and fields verifications. The lithology of the study area has been delineated light to dark tonal variations, medium to coarse texture in slightly undulating terrain. Brown to reddish brown tone with medium to very coarse texture observed in undulating terrain uneven shapes indicates granitic gneiss. This specifically shows alternate bands light dark color distinctions.

Table.4 Assigned weightages for lithology map

\begin{tabular}{|c|c|c|c|c|}
\hline Lithology & Age & $\begin{array}{l}\text { Area } \\
\text { in } \\
(\mathrm{Sq} \cdot \mathrm{km} \\
)\end{array}$ & $\begin{array}{l}\text { Weig } \\
\text { htage } \\
\text { s }\end{array}$ & Rank \\
\hline $\begin{array}{l}\text { Fluvial } \\
\text { (Block } \\
\text { Cotton soil } \\
\text { with } \\
\text { Gypsum) } \\
\end{array}$ & $\begin{array}{l}\text { Recent to } \\
\text { late } \\
\text { Pleistocen } \\
\text { e - } \\
\text { cainozoic }\end{array}$ & 15.322 & 2 & Medium \\
\hline Granite & $\begin{array}{l}\text { Migmatite } \\
\text { complex - } \\
\text { archean }\end{array}$ & 23.782 & 3 & Low \\
\hline $\begin{array}{l}\text { Hornblende } \\
\text { Biotite } \\
\text { gneiss }\end{array}$ & $\begin{array}{l}\text { Migmatite } \\
\text { Complex - } \\
\text { Archean }\end{array}$ & $\begin{array}{l}536.69 \\
9\end{array}$ & 3 & \\
\hline Charnockite & $\begin{array}{l}\text { Migmatite } \\
\text { Complex - } \\
\text { Archean }\end{array}$ & $\begin{array}{l}186.55 \\
2\end{array}$ & 1 & High \\
\hline Water body & - & 6.947 & 1 & \\
\hline
\end{tabular}

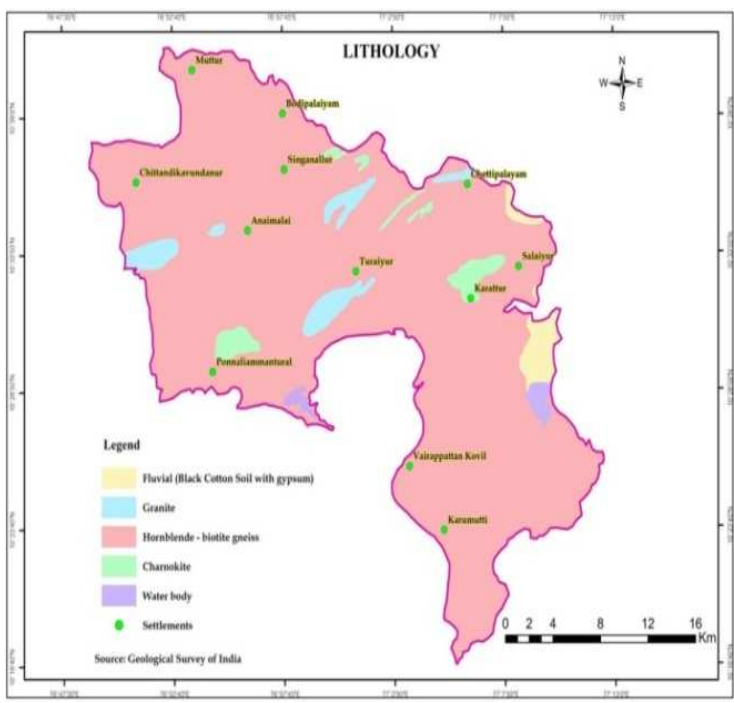

Figure.7 lithology map

\section{INTEGRATION OF THEMATIC MAPS}

All the thematic maps were integrated with suitable ranks and weightages factor using ARC/ INFO geographic information system (GIS) software packages in order to delineate the ground water potential zones.

The different thematic layers were integrated with one to each through GIS using operations like union and functions. First the all thematic layers have been arranged for union for one another according to their relationship with weathering characteristics, chemical compositions, and infiltration capacities. The following methods are follows for the integration purposes.in the first geomorphology assigned as, land use / land cover map assigned as. Both were integrated one another and the resulting product assigned as. In the second step combined with geology map and the resulting product assigned as. In the third step integrated with subsurface lithology map the resulting product assigned as. Finally integrated with lineament density map the resulting product assigned as. So the final product maps the all combinations.

\section{GROUNDWATER POTENTIAL ZONE}

Demarcation of ground water potential zones has been developed by grouped the polygons of integrated various thematic maps of different categories. These categories are good, moderate and poor which are derived adding the entire thematic layer. 


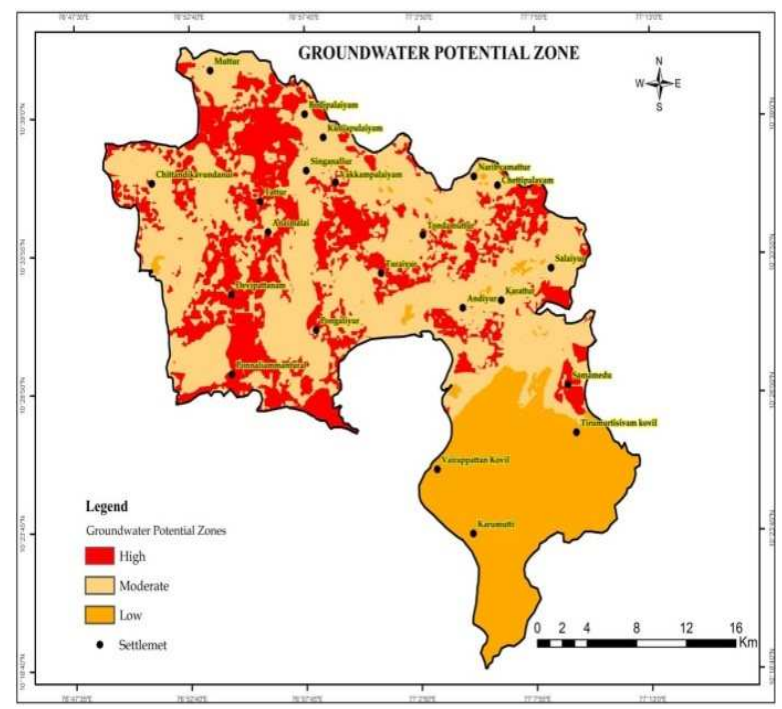

Figure.8 groundwater potential zone

\section{RESULTS AND DISCUSSION}

The present study is concluding like this for terrain analysis the remote sensing is best suitable technology. Remote sensing provides information of an area which in a short time at low cost. The information which is obtained from the satellites involves all sort of information of the area. Remote sensing also provides continuous monitoring of the area, environmental monitoring, climatic condition, changes and also provides information on seasonal variation etc.For geographical, geomorphologic mapping, hazards management, resource estimation, urban planning and to study the agriculture practices remote sensing techniques is suitable technique. By this technology information on a terrain can get for a micro level of all aspect. The data obtained from this technology is user friendly and multidisciplinary.

\section{CONCLUSIONS}

The groundwater potential zone of any area is depends on geological formations; geomorphologic unit's recharges characters, topography, and thickness of weathered and fractured zones.In the present study, area was taken to locate groundwater potential zones by integrated different thematic maps, remote sensing and geographic information system techniques. To find out the ground water potential zones, different thematic maps have been prepared and integrated each of them. They are mainly geology, geomorphology, land use/ land cover, lineament etc.

Geologically the investigated area comprised by hornblende Biotite gneiss, granitic rocks and isolated pockets of quartzite's veins. Geomorphologically the area classified into 3 categories. They are buried pediment deep buried pediment shallow, buried pediment moderate. Lineament map, drainage map has been prepared from the Toposheet /imageries. Groundwater potential zones have been prepared with help of integrating different thematic maps.

\section{REFERENCES}

[1]. MurugasenVasanthavigar, rishnarajSrinivasamoorthy, KannusamyVijayaragavan, SelvarajGopinath and SubramanyaSarma (2011). Groundwater potential zoning in Thirumani-muttar sub-basin Tamilnadu, India-A GIS and remote sensing approach Geo-spatial Information Science, 14(1):17-26.

[2]. Ganesh Babu O, MC Sashikkumar (2010). Demarcation of groundwater recharges potential zones for Tiruppur block using GIS. Journal of soil and water conservation, 9, pp 154-158.

[3]. Sukumar S, Sankar K (2010). Delineation of potential zones for artificial recharge using GIS in Thenidistrict, Tamilnadu, India" International journal of geomatics and geosciences Volume 1, ISSN 0976-4380.

[4]. Krishnamurthy, J., Mani, A.N., Jayaram, V. and Manivel, M (2000), groundwaterresources development in hard rock terrain: An approach using remote sensingand GIS techniques. International Journal of Applied Earth Observation andGeoinformatics, 2, pp 204-215.

[5]. Anbazhagan S, Ramasamy SM, Gupta DS (2005) Remote sensing andGIS for artificial recharge study, runoff estimation and planningin Ayyar basin, Tamil Nadu, India. Environ Geol 48:158-170

[7]. Chenini I, Benmammou A, Elmay M (2010) Groundwater recharge zone mapping using GIS-based multi-criteria analysis: a casestudy in central Tunisia (Maknassy Basin). Int J Water ResourManag 24:921939

[8]. Choudhury PR (1999) Integrated Remote Sensing and GIS Techniques for Groundwater Studies in Part of Betwa Basin Ph.D.Thesis (unpublished), Department of Earth Sciences, University of Roorkee, India

[9]. Krishnamurthy. J, Manavalan.P \&Saivasan. V (1992). Application of digital enhancement techniques for groundwater exploration in a hard rock terrain. International Journal of Remote Sensing, 13(15), 2925-2942.

[10]. Krishnamurthy. J, Kumar. N. V, Jayaraman, V \&Manivel, M. (1996). An approach to demarcate groundwater potential zones through remote sensing and geographic information systems. International Journal of Remote Sensing, 17(10), 1867-1884.

[11]. Krishnamurthy, J., Kumar, N. V., Jayaraman, V., \&Manivel, M. (1996). An approach to demarcate groundwater potential zones through remote sensing and a geographic information system. International Journal of Remote Sensing, 17, 1867-1885. 


\section{BIOGRAPHIES}

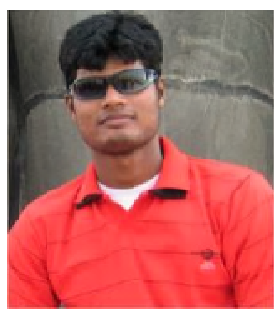

M. Pandian has completed B.Sc. (chemistry) from Urumu Dhanalaksmi College, Bharathidasan University, Tiruchirappalli-23, Tamil Nadu, India and Pursuing M.Tech (Geo-Technology \& Geo-Informatics) in Centre for Remote Sensing, Bharathidasan University, Tiruchirappalli-23, Tamil Nadu, India. He has presented paper national conference, cash awarded held on IRS Anna University, Chennai. His Research interest includes Remote Sensing and GIS and Hydrology. 